ljtihad: Jurnal Wacana Hukum Islam dan Kemanusiaan

Vol. 20, No. 2 (2020), pp. 235-252, doi : 10.18326/ijtihad.v20i2.235-252

\title{
Fulfillment of civil rights of extramarital children and its effect on social dimensions
}

\author{
Alfian Qodri Azizi, Ali Imron, Bagas Heradhyaksa \\ Faculty of Sharia and Law, Universitas Islam Negeri Walisongo Semarang \\ E-mail:alfianazizi@walisongo.ac.id, ali.imron@walisongo.ac.id, bagashera@walisongo.ac.id \\ DOI: 10.18326/ijtihad.v20i2.235-252
}

\begin{abstract}
This article analyzes the fulfillment of extramarital children's civil rights, which has become a controversy since the issuance of the Constitutional Court decision no. 46/PUU-VIII/2010, which is considered a progressive and responsive measure to guarantee children's rights. However, the content of this decision is considered to violate Islamic norms in giving family lineage to extramarital children, for it will create a stigma that one does not need a sacred marriage institution if he only wants to establish a civil or lineage relationship with his biological father; instead, it only requires evidence based on science and technology or others in court. This article answers the questions of how to interpret the concept of the civil rights of extramarital children to avoid conflicts with Islamic norms and what are the philosophical and sociological benefits of fulfilling civil rights for extramarital children. This study is qualitative in nature. It is focused more on conceptual ideas based on library research using conceptual and case approaches. It was found that (1) the civil rights of extramarital children are not a lineage right but compensation from their biological father as a form of moral responsibility; (2) philosophically, the civil rights of extramarital children are to fulfill the value of social justice which is distributive while, sociologically, these rights create a prosperous social condition for society by fulfilling the civil rights of the next generation of the nation covering their physical, mental, spiritual, and intellectual needs.
\end{abstract}

Tulisan ini meneliti tentang pemenuhan hak keperdataan anak luar nikah yang menuai kontroversi sejak dikeluarkannya putusan MK No. 46/PUU-VIII/2010. Satu sisi langkah MK tersebut dinilai merupakan langkah progresif-responsif untuk menjamin hak anak. Namun di lain pihak, isi Putusan MK dianggap melanggar norma hukum Islam dalam hal memberikan nasab kepada anak luar nikah, karena akan menimbulkan stigma bahwa seseorang tidak perlu lembaga pernikahan yang sakral jika hanya menghendaki terjalinnya hubungan perdata atau nasab kepada ayah biologisnya, cukup dengan dibuktikan berdasarkan ilmu dan teknologi atau alat bukti lain di Pengadilan saja. Problem yang hendak dipecahkan dalam tulisan ini adalah bagaimanakah memaknai konsep hak keperdataan 
anak luar nikah agar tidak bertentangan dengan norma Islam? dan apakah manfaat pemenuhan hak keperdataan bagi anak luar nikah secara filsosofis dan sosiologis?. Kajian penelitian ini ada pada ranah kualitatif yang sifatnya lebih mengarah kepada gagasan konseptual berdasarkan analisis kepustakaan (Library Research) dengan menggunakan pendekatan konseptual (conceptual approach) dan pendekatan kasus (case approacb). Hasil dari penelitian ini adalah: 1) hak keperdataan anak luar nikah bukanlah hak nasab melainkan sebagai bentuk ganti rugi yang diberikan dari ayah biologisnya sebagai bentuk tanggung jawab moral, 2) manfaat hak keperdataan anak luar nikah secara filosofis adalah memenuhi nilai keadilan sosial yang bersifat distributif, sedangkan secara sosiologis adalah untuk menciptakan kondisi sosial masyarakat yang sejahtera, dengan cara memenuhi hak-hak keperdataan generasi penerus bangsa yang mencakup kebutuhan fisik, mental, spiritual, dan intelektual mereka.

Keywords: fulfillment; civil rights; extramarital children.

\section{Introduction}

Currently, child neglect has become a concern in Indonesia. Innocent children become victims of violence, persecution, and even inhuman murder, because of their unexpected presence due to rape, adultery, or unreadiness of their biological parents to care for and raise them. This country has stipulated a series of legal rules as a serious guarantee for children's rights, which aims to create a qualified generation who will continue the struggle of the nation and religion in the future. Some of these regulations are contained in Law No. 35/2014 jo No. 23/2002 concerning Child Protection, Law No. 1979 on Child Welfare, and Presidential Decree No. 36 of 1990 as a form of ratification of the Convention on the Rights of the Child by the United Nations. These normative rules put forward the obligation to protect children based on the principles of the best interest of the child, the right to grow and develop, the right to life, anti-discrimination, and respect for children's opinions (Pancasilawati, 2014: 172).

A child born from a mother's womb actually comes from a male sperm, but the dichotomy of the child's status may differ according to the provisions of Islamic law and the Marriage Law in Indonesia. Legitimate children have a clear status and are legally and formally guaranteed for the full fulfillment of their rights (Edyar 2016, 183), including having a family lineage (nasab), inheritance, and guardianship with their biological father. The Marriage Law Article 2 paragraphs (1) and (2) outlines the validity of marriage if it is carried out based on the legal rules of religion and belief and registered according to the 
applicable law's rules. However, it is different for extramarital children, such as adultery children, children from unregistered marriages (sirii), contract marriage, etc. They only have a civil relationship with their mother, as stated in Article 43 UUP No. 1/1974, prior to a judicial review through the Constitutional Court's (MK) decision No. 46/PUUVIII/2010. Meanwhile, the biological father holds no obligations as a parent legally.

The problem of extramarital children had become a booming phenomenon in 2012 . There was a controversy on the Constitutional Court's decision because of its revised Article 43 of Law No. 1/1974. The previous article that read "Extramarital children only have a civil relationship with their mother and their mother's family" had been changed to "Extramarital children have a civil relationship with their mother and their mother's family and with a man as their father, which can be proven by science and technology and/or other evidence, which, according to the law, has blood relations, including civil relations with their father's family." The Constitutional Court's judicial review was related to the petition by Machica Muchtar, who wanted her unregistered child with Moerdiono to be legally recognized as a legitimate child even though there was no administrative evidence record.

The verdict issued by the Constitutional Court actually exceeded what Machica Muchtar expected as the party who submitted a material test. At first, she only wanted her unregistered child to be recognized as Mordiono's son so that he would get full lineage and civil rights from his biological father (Taufiki, 2012: 59). However, the Constitutional Court decided more by changing the substance of Article 43 of Law No. 1/1974, resulting in a social domino effect. Instead of providing legal protection for children with the principle of anti-discrimination and the child's best interests, the Constitutional Court was presumed by some legal experts to violate Islamic norms. On one side, the Constitutional Court took a progressive measure by making legal changes by considering social aspects to eliminate the negative stigma of "illegitimate children", potentially harming children both psychologically and socially. Basically, a child is born in a state of purity. He does not inherit the innate sins of his parents. If he had a choice, he would not want to be born from parents who had an affair. Therefore, all children born under any conditions should receive guarantees before the law to fulfill their rights. They must not have bad luck over 
and over again. They have been entitled as a disgrace to society and even lose their rights like misfortunes that never come singly. Children who are actually the victims must feel the bitterness of bearing shame in society for the rest of their lives because of their parents' moral actions.

On the other hand, the impact of the Constitutional Court's decision is also alleged to violate Islamic norms, which are final and absolute. The Indonesian Ulema Council (MUI) strongly opposed the Constitutional Court's decision because it lets unregistered children get civil rights with their biological father. It contrasts with Islamic dogma if the civil rights referred to the Constitutional Court mean the family lineage's right. Islam views that only children from a marriage that meets conditions and pillars of Islamic law are entitled to bear their biological father's lineage, while illegitimate children only have a lineage with their mother.

Based on this background, this article discusses the interpretation of extramarital children's civil rights to apply the legal rules and the benefits of fulfilling such rights for the social dimension. It discusses the problem of implementing the Constitutional Court's decision, which is considered contrary to Islamic norms and answers the problem of extramarital children considered discriminated against by the existing legal provisions.

\section{Method}

This library research analyzes the Constitutional Court's decision regarding the civil rights lawsuit of Machica Moehtar's extramarital child. The approaches used include (1) the case approach to explaining the legal reasons (ratio decidendi) of the Constitutional Court's decision regarding extramarital children and (2) the conceptual approach to describe the opinions of legal experts for a comprehensive understanding of the philosophical and sociological substance of the legal rules of civil rights fulfillment of extramarital children (Suhaimi, 2018). The data were obtained from the primary source, the Constitutional Court's decision No. 46/PUU-VIII/2010, and the secondary source was from various legal study materials related to the problem under study. The data were then analyzed descriptive-analytically to draw general conclusions from the research object as a whole and present it in-depth, systematically, clearly, and in detail (Soekanto, 2006). 
Fulfillment of civil rights of extramarital children and its effect on social... (Alfian Qodri Azizi, et. al)

\section{Previous research}

This article differs from the existing works because it explains more about the implementation of extramarital children's civil rights, hence they do not conflict with Islamic norms and the benefits of fulfilling such rights for the social dimension. The existing articles have not discussed the implementation of the Constitutional Court's decision. They were only concerned with the interpretation of the decision, which clashes with Islamic norms.

Nur Azizah's article entitled “The Constitutional Court's Decision No. 46/2010 concerning the Civil Relations between Extramarital Children and Biological Fathers" concluded that there was no clear interpretation by the Constitutional Court of the meaning of the extramarital children's civil rights, leading to pros and cons in various perspectives. Unregistered children can then obtain their rights with technological proof that they result from a biological relationship of their father's unregistered marriage (Azizah, 2018).

Nasaiy Aziz, through her work entitled "The Nasab of Extramarital Children: the analysis of the Aceh Ulama Consultative Council (MPU) Fatwa Number 18 of 2015 and the Constitutional Court's Decision Number 46/PUU/-VIII/2010" explained that the Constitutional Court considers that the lineage of illegitimate children that was cut off from a man who commits adultery is a form of discrimination. Meanwhile, the Aceh MPU states that an extramarital child's lineage only to the mother is not a form of discrimination against children.

Finally, Ardian Arista Wardana wrote an article entitled "Recognition of Extramarital Children: Juridical Review of the Status of Extramarital Children," explaining that extramarital a child has the right to receive the legal status when his father acknowledges him with scientific evidence. However, the Constitutional Court's decision must be appreciated because it has tried to provide children with rights from their parents (Wardana, 2017).

\section{Theoretical framework}

According to Gustav Radbruch, the philosophical objective of the law is to achieve the values of legal justice, usefulness, and certainty that are related to each another. Justice means that all people are equal before the law without any discrimination of gender, economic status, political power, clan groups, etc. The second aspect, usefulness, means 
that law must have a beneficial value that provides benefits, happiness, or satisfaction to society. Abstractly, the law has a useful value if it can prevent evil or gain good. Evil causes suffering, while goodness causes happiness (Azizi, 2016). The third aspect, legal certainty, is needed to ensure that the ideal values of legal justice and usefulness that lives and develops amid human interactions are appropriately applied. These two values are stated in a sovereign country's positive legal rules, containing orders or prohibitions and legal sanctions as an operational framework for implementing law consequently and sustainably (Tanya, Simanjuntak, and Hage, 2010: 171).

Besides, sociologically, the law should also reflect the values that live and develop in society because, if the law is too rigid, inflexible, it will create complex problems that lead to horizontal conflicts. Laws that are acceptable and adaptive according to the characteristics of society are easier to implement. Therefore, the law is not only a pile of written rules but also a dialogical result of the existing social conditions (Imron, 2016: 123). Absolute Islamic law must also be transformed into national law in humanist and down-to-earth manners so that the Indonesian people consciously and voluntarily comply with it and obey to implement it.

\section{Discussion}

\section{Interpretation of civil rights of extramarital children}

Islamic teaching has different criteria of illegitimate or extramarital children from, for example, adultery (zina) and allegation of adultery (li'an), compared to Indonesia positive law. In Islam, adultery is defined as sexual intercourse both within and outside marriage between a man and a woman, while Article 284 of the Criminal Code defines adultery more specifically, i.e., sexual intercourse for a married man and woman only. This specified definition has a juridical consequence that only someone who has a husband or wife is punished for doing sexual intercourse, while the unmarred who have sexual intercourse are subject to a criminal punishment as long as there is no coercion and violence (Ishak, 2012:167). In Islam, if the adulterer is not married (ghairumubson), the punishment is 100 lashes and being exiled for one year, but for the married adulterer (mubson), the punishment is stoning to death (Mohtarom, 2018: 194). 
According to Islamic law and Burgerlijk Wetboek (BW), there are different legal consequences between extramarital children. Extramarital children in Islam must/ automatically have a family lineage with their mother only, but extramarital children in BW do not automatically establish a civil relationship with their mother; a child obtains the civil relationship after his biological mother acknowledges him. Extramarital children (zina), according to Islamic law, cannot have a family lineage with their biological father. However, for a child in the category of "naturlijke kinderen", namely a child from a relationship between a man and a woman without a marriage bond, who both have no prohibition against marriage by BW, he can get a civil relationship with his biological father through the recognition (erkenning) method and child ratification (wettiging). After recognition and ratification, the child is then bound by a family relationship, giving him a civil impact, especially the right to inherit between the child and his two parents, as stated in Article 280 K.U.H. Civil Code (Febriansyah, 2015: 8).

Recognition and ratification of naturlijkekinderen children can be carried out at the time of marriage by registering extramarital children's names in the marriage book as legitimate children. Submitting a letter of ratification (brieven vanwettiging) to the president can an alternative way to recognition and ratification, in which the president must ask for consideration from the Supreme Court in making a decision (Latumahina, 2014: 368). It is to be underlined that incest (bloedschenning), namely a child born from forbidden relationships, such as siblings' blood relations, and children from adultery not allowed by BW to get recognition based on the provisions of articles 283 and 272 of the Civil Code.

From the normative perspective, the Constitutional Court's Decision No. 46/PUUVIII/2010 has attempted to take progressive measures to fulfill the rights of extramarital children, especially those subject to the Civil Code, as the assumption built by progressive legal idealism that law exists for humans, not to force humans to comply. The law must comply with the demands of justice and give happiness and protection. The progressive measures that emerge in the decision can be seen from several things. First, if the initial recognition and ratification of extramarital children as stipulated in BW only depends on the parents' initiative and they do not want to recognize and legalize, they will lose their right to care for and education. However, after the issuance of the Constitutional Court's 
decision, the extramarital child or an interested party (his mother) has the initiative to sue or request civil rights from his biological father by proving it in front of the court. Second, naturlijkekinderen extramarital children can receive recognition and ratification as regulated in the Civil Code, but incest and adultery children also have the right to have a civil relationship with their biological father. Third, extramarital children can obtain an inheritance relationship, which is limited to their parents who admit them, while the members of the outside family have no legal relationship. Fourth, Article 289 of the Civil Code prohibits incest and adultery children from finding out their parents. After the Constitutional Court's decision, they have the right to know their father and mother.

The Constitutional Court has indeed decided by considering humanitarian reasons. The process of childbirth involves the relationship between a boy and a girl for fertilization, by meeting the egg and sperm through natural sexual intercourse (coitus) or by using technological methods such as IVF (In Vitro Fertilization). IVF is a medical procedure that involves the retrieval of oocytes (egg cells), which are then fertilized with sperm to form an embryo to be transferred/inserted into the mother's uterus (womb). Thus, it would be unfair if a child born due to a relationship without marriage eliminates all ties and responsibilities of the father to his child, even though the blood relationship between the two can actually be proven by medical technology. Therefore, the administrative issue of marriage registration, in this case, has been secondary to achieving the legal goal of providing protection to innocent children and keeping them away from bad stigma and public scorn due to not having father status. Nevertheless, on the other hand, instead of offering responsive legal products, the Constitutional Court's decision actually created obstacles in the application process because many Islamic jurists considered that it hit the signs of religion. It is because there are no regulations that explain in more detail what the civil rights of extramarital children are, and most people think that the civil relationship of the extramarital children is in line with that of the lineage, even though Islam strictly prohibits the right of the extramarital child to get a lineage with his biological father, as stated in the Compilation of Islamic Law Article 100. Moreover, the Constitutional Court's decision can be interpreted, a person no longer needs to marry, if he only wants a civil bond between the child and the family of his parents, because extramarital children without 
a legal marriage bond can be recognized as long as it can be proven legally or technology.

According to the author as a problem solving, the word "civil rights of children out of wedlock" in the Constitutional Court decision should be interpreted as a right that children can demand from their biological father as compensation or as a moral responsibility of the father to the child, in order to meet material needs such as educational needs, care, and maintenance for the child's development, so that the biological father of the extramarital child does not just run away from responsibility to his child. It is as explained by Mahfudz MD that the civil relationship established by the Constitutional Court is not a lineage relationship because the lineage relationship cannot be determined by the Constitutional Court (Indonesia Lawyers Club, 2017). Family lineage exists because of a valid marriage bond, the terms and conditions, namely the fulfillment of a guardian, witnesses, consent granted, husband and wife candidates according to Article 14 of the KHI. Manuscripts lead to a special relationship between the child and their parents, for example, a guardianship relationship with their father. If a woman wants to marry, her father must be her guardian; it is the parents' obligation to provide a living and obtain inheritance rights.

Meanwhile, civil relations are legal relationships between a person and another that arise to rights and obligations. Civil relations can arise because of "agreement" or "because of events". For example, a civil relationship arises because of an "agreement" such as a legal marriage according to religion and is registered, so a child born from that marriage has the right of lineage and gets a civil relationship because it is registered. However, if the marriage is not recorded, then the civil relationship arises because no agreement has been recorded. Another example of a civil relationship that arises as a result of an "incident", for example, a man committing adultery and then having a child, because there is no agreement (legal and recorded marriage contract) the child can claim compensation from a man who has intercourse with his mother because the result of the man's actions causes harm to the child as the child's good name becomes tainted. It is the same as someone bumping into another person; there is no need for an agreement between the two, but whoever crashes must be responsible. It is legally regulated in article 1365 of the Civil Code, which contains a person because an act against the law causes harm to a person; he is obliged to provide compensation. 
ljtihad: Jurnal Wacana Hukum Islam dan Kemanusiaan, Volume 20, No. 2, Desember 2020: 235-252

\section{Benefits of fulfilling civil rights for extramarital children}

One of the philosophical goals or legal ideals to be achieved by the Indonesian State is to realize social justice, as contained in the 5th principle of Pancasila and the 4th paragraph of the 1945 Constitution preamble. One of the basic principles in the value system of social justice is the recognition of human dignity based on the principle of "equal rights" for all elements of society. On the contrary, the meaning of social injustice is an attitude that discriminates against others, as expressed by J. Rawls that "injustice, then, is simply inequalities that are not to the benefit of all" (Rawls, 1971: 62). Rawls emphasizes more the existence of a balanced and stable community life between individual interests and collective social interests. Rawls believes that to achieve social justice, society's basic structure must be built based on the principles of freedom, opportunity, authority, power, welfare, and the fulfillment of each individual's fundamental rights.

The fundamental human rights, as described in the Universal Declaration of Human Rights (DUHAM), include the right to life, the right of support (the right to eat, clothing, and shelter), the right to get medical services, freedom from torture, and freedom of religion (Jatmiko, 2018: 224). The "equal" condition of society becomes a barometer to measure the extent to which social institutions have worked effectively to achieve the value of justice or correct in the event of injustice in society. The same thing was expressed by Kamali that social justice is a condition in which society strives for an equal situation. To emphasize even more, justice must be able to provide guarantees for all people so that their human rights "cannot be eliminated" even though based on promoting the welfare of society as a whole (Ramadhan, 2011: 50).

Besides affirming the equality principle, J. Rawls also reveals the other side of social justice, which also opens up the possibility of differences in society's basic structure. On condition, the difference is still beneficial to provide welfare for less fortunate people (Lebacqz, 2015: 58). The social justice principle must be encouraged to correct public policies related to politics, economy, social, and culture, which are not pro towards the weak. If the social justice principle, which emphasizes the existence of "the principle of rights' equality", is linked to cases of extramarital children, such as children from adultery (zina) and children from unregistered marriages (sirri), then serious problems arise. It is 
because an illegitimate child only has a civil relationship with his mother and is cut off from his family lineage with his biological father so that the father's legal obligations to support, care for, educate, become the guardian of marriage for a daughter, and pass his property to the biological child are annulled; all these obligations are borne to the mother.

It contradicts the principle of equal rights, which is the jargon of social justice and creates a sense of injustice. A sense of injustice, according to J.s Mill, can arise from two things. The first is if a person is deprived of his rights; it is the same as what happens to extramarital children who lose their rights of support, education, care, inheritance, etc. due to the absence of a lineage relationship with their biological father. The second is that injustice arises from imperfect responsibilities (Lebacqz, 2015: 20), as happens to extramarital children. The mother has to work hard to provide for the children, while the father is free from this moral obligation.

Not only that, the dismissal of the biological father's responsibility for extramarital children is counterproductive to the constitutional mandate of the 1945 Constitution Article 28, which explains that every child has the right to survive, grow, and develop and is entitled to protect from violence and discrimination. It also contradicts Law Number 39 the 1999 concerning Human Rights in Article 3 paragraphs 2 and 3, which state that everyone has the right to recognition, protection guarantees, and fair legal treatment as well as legal certainty and equal treatment before the law; everyone has the right to protection of human rights and basic human freedoms without discrimination. Furthermore, it is also contrary to the rules of international law, namely the Universal Declaration of Human Rights, which reads in article 25 paragraph 2 that "All children, whether born in or out of wedlock, shall enjoy the same social protection".

From the author's observations, the Constitutional Court's decision to conduct a judicial review of Law No. 1 of 1974 departed from the value of social justice, which emphasizes the equality principle. However, the Constitutional Court's formulation of article 43 of the Marriage Law No. 1/1974 can trigger social anomalies because people will think that children born because of promiscuity or pregnancy outside of marriage can have a lineage relationship with their biological father as long as it can be proven by developing technology, for example by DNA testing. People will underestimate the sacred marriage bond that results 
in adultery practice everywhere. From the social side, the wisdom in Islamic legal norms can be understood regarding the prohibition of lineage relationship between children from adultery and their biological fathers, namely, to prevent community mafsadat (damage) arising from free sex behavior, such as HIV/AIDS and other infectious diseases. The marriage regulation is a sacred social contract whose function is to protect the honor of humans themselves so that their lineage is not messed up. Moreover, as caliph on earth, humans should protect human life so that they become civilized people. Islam classifies children's status as legitimate and illegitimate, not to create discrimination against children's rights, but rather to implement the maqhasidus syari'ah, namely the principle of khifdzu al-nasl (safeguarding offspring) and closing the door of adultery (Zakyyah, 2016: 195).

Therefore, the protection of the extramarital children's rights, according to the Indonesian Ulema Council's (MUI) opinion, is not by making lineage relationship against a man who commits adultery (his biological father) but imposing "ta'zir" punishment to the man. It is a form of responsibility to meet the children's daily needs and provide assets through wasiat wajibah (compulsory wills) after he dies (Pusvita, 2018: 46). Giving ta'żir, which is the authority of ulil amri, is an alternative effort because the hadd (whipping and stoning) sanctions for adulterers are not enforced. It is good enough rather than ordaining an illegitimate child to his biological father. Legal sanctions have crucial benefits as a social order tool, whose function is to bind a person to submit to and be motivated to carry out established legal norms (Azizi, 2020).

The MUI fatwa is in line with the decision of the 2012 National Working Meeting of the Supreme Court of the Republic of Indonesia, which declared that children from extramarital relations and unregistered marriages (sirri, including mut'ah marriages) have the right to earn a living and share a portion of their biological father's inheritance through a compulsory will (Arto, 2019: 1, 5). According to the author, the MUI fatwa and the decisions of the National Working Meeting of the Supreme Court of the Republic of Indonesia are in accordance with the value of social justice when referring to J Rawls's theory of distributive justice, which states that there may be differences in rights between individuals, provided that they do not harm the less fortunate (Kymlicka, 2011: 71), in this case, children are born from an illegal marriage bond. The distinction against illegitimate 
children, by not getting lineage relationships (civil rights) with their biological father, is intended to maintain greater moral values; hence no free sex occurs in society and to uphold the social justice principles. Differences are allowed as long as they still provide benefits (protection) for someone who is suffering from social inequality as a result of their natural conditions (Kymlicka, 2011: 74), as in a child from an illegal marriage bond, who is also entitled to receive a living and a compulsory will from his biological father.

A man's obligation to fulfill a living, maintain, educate, and provide a compulsory will to extramarital children is a consequence of the legal event of the children's birth. These legal events create a reciprocal relationship between legal subjects, namely parents and children, to be mutually responsible for each other's rights and obligations. Therefore, it is irrelevant if a man who, in fact, has had intercourse with a woman causes a pregnancy to be freed from

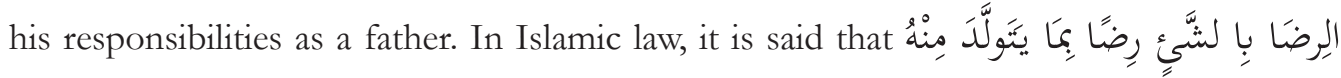
signifies "being willing to do something means being willing to bear the consequences of that action" (Mujib, 2013: 76).

The fulfillment of children's civil rights is beneficial for protecting children's fundamental rights and fulfilling their best interest to achieve their self-welfare (Imron 2013, 264). In the future, children will be the heirs and successors of the nation's civilization. Therefore, as the leader and protector of all family members, the father must not ignore the fulfillment of the children's civil rights. The children's rights are one of the media in preparing the young generation from an early age to create a prosperous society.

Fulfillment of children's civil rights greatly affects the aspects of children's selfdevelopment in terms of physical, psychological, and intellectual (Azizi, 2019). Children's physical health aspects can be maintained by fulfilling their daily food needs, supported by good nutritional needs. It is why there is a concept of giving a living or wages for a mother who is breastfeeding by the child's father in Islam; it aims to maintain the child's nutritional needs from an early age (Surah al-Baqarah [2]: 233). Therefore, in the next growth process, the physical condition and intelligence of the children's brains can develop optimally. Therefore, husbands should not be negligent and always try to fulfill the needs of care for children. They should fulfill their children's basic needs, including nutritious food, clothing, and a clean place to live, as well as childcare and medical expenses, as mandated by the KHI 
article 80. Efforts to fulfill a living to maintain a child's physical health should have been done by the father since the baby was in the womb (Article 45 of the Child Protection Law No. 35 of 2014).

The existence of a civil relationship between father and son, in essence, is not only meeting economic fulfillment but also improving the emotional quality of the relationship between the child and his parents, hence both of them will have a strong inner bond. It is beneficial for children's optimal growth and development, spiritually, physically, and psychologically. With parents' responsibility to fulfill their children's needs, care, and education, children do not need to worry, let alone have to work on their own to find money to meet their economic needs. It also serves to prevent children from social-environmental disturbances that can hinder their growth if they have to work alone (Sajogo and Budiyono, 2015: 3).

Furthermore, the aspect of improving the children's intellectual quality is the parents' responsibility to provide education, since education is a crucial aspect in the present era. The impact of globalization's current wave has made many citizens of the world rethink the importance of their human resources' (HR) quality. Various countries strive to "boost" human resource development to color and contribute to the global arena. One of the particular concerns by various countries in the world in the context of improving human resources is regarding education quality. Inevitably, education for children needs to be considered by their parents as early as possible so that children as the nation's budding can become qualified human beings, armed with knowledge and religious knowledge.

The provision of knowledge can be used to face the current modern era, where we are required to compete massively abroad and domestically. Whether a nation's strength is ready or not will be tested by being exposed to globalization, which brings about the 4I phenomenon: information technology, individual consumers, industry, and investment (Setiawan, 2013: 62). If the Indonesian people's human resources cannot compete, they will only become slaves in their own homes, considering that the current globalization opens wide the flow of goods and services from international markets. Of course, many foreign investors come to reap profits in Indonesia. Instead of being a victorious nation, the Indonesian people are like dead chickens in a rice barn. Indonesia, which is gifted with extraordinary natural resources, cannot use them for the nation's prosperity. It is due to the 
lack of human resources owned, as a result of a lack of knowledge to process, manage (good governance), and preserve Indonesia's natural wealth in good ways. Indeed, we do not want this to happen to our nation; the negative stigma as an inland nation needs to be buried in past colonization memories.

In this case, the provision of religious knowledge can guide a person to live with religious values, respect life, and do things useful for life together. Humans who forget the essential life values will fall into the shadows of materialism that emphasizes worldly pleasures, far from religious, moral values, so that they live like zombies with bodies without spirits. They are still alive, but their life conscience is dead. As a result, their behavior in life is oriented only to destroy, not to provide benefits. Greed, wrongdoing, arrogance, stealing, and corruption become their daily without feeling guilty.

\section{Conclusion}

From the description above, it can be concluded that the polemic regarding children's civil rights, which are deemed to violate the norms of Islamic law, can be harmonized by implementing the civil rights granted to extramarital children, not interpreted as rights of lineage relationship, but as a form of compensation by giving punishment (ta'zir) to the biological father to take responsibility for what he did. It is by paying the cost of care, education, and health for children, as well as giving the inheritance from the biological father through a compulsory will when he dies later. The purpose of imposing this sanction is to have a psychological impact on adulterers so that they do not just lose their responsibility.

In the philosophical realm, granting the civil rights of extramarital children is beneficial to achieve the social justice value that is distributive in nature, indicating that all children get their rights. However, the fulfillment of the rights obtained is not the same, according to the child's status, to maintain society's moral values. Besides, the fulfillment of children's civil rights, encompassing the cost of food, education, and care of children, has benefits to achieving individual welfare (private interest) for each child and has universal or general (public interest) dimensions for realizing a prosperous social society (civil society). The fulfillment of children's civil rights functions as an effort to prepare human resources who have superior potential, physically, mentally, spiritually, and intellectually to meet the future 
ljtihad: Jurnal Wacana Hukum Islam dan Kemanusiaan, Volume 20, No. 2, Desember 2020: 235-252

to face the challenges of an era that continues to develop and move forward.

As a suggestion, the author considers the need to add explanations to article 43 of the Marriage Law No. 1/1974 and article $100 \mathrm{KHI}$, which regulates the status of extramarital children, in addition to only having a civil relationship with their mother and their mother's family, children also receive a living and compulsory will from their biological father. The function of this addition is to provide a sense of justice and guarantee legal certainty for the fulfillment of children's rights even though the marital status of the parents is still in dispute.

\section{Bibliography}

Arto, Mukti. "Gugatan Nafkah Anak Luar Nikah Sebagai Ta'zir dan Penyelesaiannya di Pengadilan Agama.” Badilag: Vol. 1, No. 5. (2019): p. 1-26.

Azizah, Nur. "Putusan MK No. 46/2010 Tentang Hubungan Keperdataan Antara Anak Luar Nikah dengan Ayah Biologis (Analisis dalam Perspektif Hukum Islam, Hukum Positif, UIDHR, dan UDHR)." Fitrah: Jurnal Kajian Ilmu-ilmu Keislaman Vol. 4, No. 2 (2008): p. 243-60.

Azizi, Alfian Qodri. "Jaminan Hak Nafkah Anak dalam Hukum Keluarga Islam di Indonesia.” Program Pasca Sarjana UIN Sunan Kalijaga, 2016.

Azizi, Alfian Qodri. "Filosofis Kewajiban Nafkah Anak dalam UUP Islam Indonesia." JAS: Jurnal Abwal Syakhshiyyah Vol. 1, No. 2 (2019): p. 55-67.

Azizi, Alfian Qodri. "Sanksi Pengabaian Hak Alimentasi Anak: Perspektif Fiqh Dan Perundang-Undangan Indonesia.” Jurnal Iqtisad Vol. 7, No. 1 (2020): p. 1-22.

Edyar, Busman. "Status Anak Luar Nikah Menurut Hukum Positif dan Hukum Islam Pasca Keluarnya Putusan MK Tentang Uji Materiil Undang Undang Perkawinan.” Al-Istinbath: Jurnal Hukum Islam Vol. 1, No. 2 (2016): p. 181-208.

Imron, Ali. "Perlindungan dan Kesejahteraan Anak dalam Perkawinan di Bawah Umur." Al-Tahrir: Jurnal Pemikiran Islam Vol. 13, No. 2 (2013): 253-272.

Imron, Ali. “Transformasi Hukum Islam Ke Dalam Hukum Nasional Indonesia.” Jurnal Ilmiah Hukum dan Dinamika Masyarakat Vol. 5, No. 2 (2016): p. 123-132.

Indonesia Lawyers Club. "Nikah Sirri Sah Atau Tidak.” 2017.

Ishak, Ishak. "Analisis Hukum Islam Tentang Perbuatan Zina dalam Pasal 284 Kitab 
Fulfillment of civil rights of extramarital children and its effect on social... (Alfian Qodri Azizi, et. al)

Undang-Undang Hukum Pidana dalam Pembaharuan Hukum Pidana.” Kanun Jurnal Ilmu Hukum Vol. 14, No. 1 (2012): p. 165-178.

Jatmiko, Bayu Jatmiko. "Menelisik Pengakuan dan Perlindungan Hak-Hak Asasi Politik

Pasca Perubahan UUD 1945.” Jurnal Panorama Hukum Vol. 3, No. 2 (2018): p. 217-246.

Kymlicka, Will. Filsafat Politik. Kontemporer: Kajian Khusus Atas Teori-Teori Keadilan, Terj. Agus

Wabyudi. Yogyakarta: Pustaka Pelajar, 2011.

Latumahina, Rosalinda Elsina. "Perwujudan Keadilan Bagi Anak Luar Kawin Melalui

Putusan Mahkamah Konstitusi Nomor 46/PUU-VIII/2010.” Yuridika Vol. 29, No. 3 (2014): p. 361-379.

Lebacqz, Karen. Teori-Teori Keadilan (Six Theories of Justice), Terj. Yudi Santoso. 5th ed. Bandung:

Nusa Media, 2015.

Mohtarom, Ali. "Kedudukan Anak Hasil Hubungan Zina Menurut Hukum Islam dan Hukum Positif." al Murabbi Vol. 3, No. 2 (2018): p. 193-202.

Mujib, Abdul. Kaidah-Kaidah Ilmu Fiqih (Al-Qawai'dul Fiqhiyyah). 2nd ed. Jakarta: Radar Jaya, 2013.

Pancasilawati, Abnan. "Perlindungan Hukum Bagi Hak-Hak Keperdataan Anak Luar Kawin.” Fenomena Vol. 6, No. 2 (2014): p. 171-216.

Pusvita, Sari. "Keperdataan Anak di Luar Nikah dalam Putusan Mahkamah Konstitusi dan Implikasinya Terhadap Harta Warisan." Ulul Albab: Jurnal Studi dan Penelitian Hukum Islam Vol. 1, No. 2 (2018): p. 31-51.

Ramadhan, Gilang. Konsep Keadilan dalam Pandangan M.H Kamali Suatu Tinjauan Filsafat Hukum Islam. Jakarta: Universitas Indonesia, 2011.

Rawls, Jhon. A Theory of Justice. London: Harvard University Press, 1971.

Sajogo, Ivana, and Didi Aryono Budiyono. "Kepribadian Anti Sosial: Fokus Kepada WhiteCollar Crime.” Jurnal Psikologi Klinis dan Kesehatan Mental Vol. 4, No. 3 (2015): p. 1-11.

Setiawan, Deny. "Reorientasi Tujuan Utama Pendidikan Ilmu Pengetahuan Sosial Dalam Perspektif Global.” JUPIIS: Jurnal Pendidikan Ilmu-Ilmu Sosial Vol. 5, No. 2 (2013): p. 52-72. Soekanto, Soerjono. Pengantar Penelitian Hukum. Penerbit Universitas Indonesia (UI-Press), 2006. 
ljtihad: Jurnal Wacana Hukum Islam dan Kemanusiaan, Volume 20, No. 2, Desember 2020: 235-252

Suhaimi, Suhaimi. "Problem Hukum dan Pendekatan dalam Penelitian Hukum Normatif." Jurnal Yustitia Vol. 19, No. 2 (2018): p. 201-210.

Tanya, Bernard L, Yoan N Simanjuntak, and Markus Y Hage. “Teori Hukum Strategi Tertib Manusia Lintas Ruang dan Generasi.” Yogyakarta: Genta Publishing, 2010.

Taufiki, Muhammad. “Konsep Nasab, Istilhâq, dan Hak Perdata Anak Luar Nikah.” Abkam: Jurnal Ilmu Syari'ah, Vol. XII, No. 2 (2012): p. 59-67.

Wardana, Ardian Arista. "Pengakuan Anak Di Luar Nikah: Tinjauan Yuridis Tentang Status Anak Di Luar Nikah.” Jurnal Jurisprudence Vol. 6, No. 2 (2017): p. 160-165.

Zakyyah, Zakyyah. "Nasab Anak Luar Kawin Menurut” Hifzhu Nasl.” Jurnal Yudisial Vol. 9, No. 2 (2016): p. 195-214. 